\title{
FORMS OF CENSORSHIP IN THE DUTCH INDIES: THE MARGINALIZATION OF Chinese-MALAy Literature
}

\author{
Hendrik M. J. Maier
}

The Minister of Colonial Affairs in the Hague wrote to the Governor-General of the Netherlands East Indies in Batavia on June 2, 1913:

Strong action should be taken against the public preaching of revolt against Dutch authorities, against those extremely tiresome efforts to discredit the best intentions of the Government, against the sowing of hate and discordance between the various races which has become the order of the day. Tolerating these manifestations or leaving their repression to the constantly varying opinion of the judiciary in the Indies-which in practice amounts to the same thing-is like committing political suicide. Moreover, it seems to me that such regulations should be applied without distinction even though the non-European press which causes the greatest possible danger for order and tranquility requires a stricter control than the European press that does not reach so far and needs the help of the native and the Chinese press to penetrate those layers of the population. Introduction of a preventive control has, of course, been made impossible by the changes in the Press regulations of 1906. Therefore, a new means of repression should be looked for, not by the judiciary but by administrative authorities. ${ }^{1}$

It was yet another comment in the continuous correspondence between authorities in The Hague and Batavia on a subject of constant anxiety-the freedom of the press. Beyond circles of administration and mission, awareness of the possibilities printing techniques offered to enterprising persons had only been awakened around 1870. Then, Dutch, Eurasian, and Chinese businessmen had initiated attempts to make money in the business of printing and publishing, their example being followed by natives some thirty years later. An increasingly wide variety of printed materials was being produced not only in Dutch but also in native languages. Of the latter, Malay had been the most important one from the beginning. This should not come as a surprise: various forms of Malay had long been the

\footnotetext{
IS. L. van der Wall, ed., De opkomst van de Nationalistische Beweging in Nederlands-Indië (Bronnenpublicaties) (Grongingen: Wolters, 1967), p. 239.
} 
main vehicles of communication in the urban centers where the first printing plants were established: Batavia, Soerabaja, and Semarang.

Troubles for authorities had formally started in 1906 when freedom of expression was sanctioned by a royal decree in the spirit of the time in the wake of Wilhelmina's memorable speech on the ethical mission the Dutch people were to carry out in the Indies. All obstructing regulations had been removed, and "an end had been made to any sort of preventive supervision of the printed word," as Kleintjes aptly summarized it in the sixth edition of his handbook on constitutional law in the Dutch Indies in 1932.2

In theory, the decree meant that administrative intervention was no longer permitted; authorities in the Indies had to resort to criminal persecution when they opined that an author or a journalist had gone too far in discrediting the best intentions of the government and should, therefore, be accused of attempting to disrupt public order and tranquility. In practice, however, authorities could still resort to the tried and tested method of intimidation; it was just a matter of giving allegedly subversive publishers or authors strong hints that unpleasant things were going to happen to them unless they stopped pen or press. No doubt this form of intimidation more often involved newspapers than literary works, but it did happen, for instance, to Tan Boen Kim and his publisher Tjiong Koen Bie in 1915 after the publication of the first part of a sequel to the novel Nona Fientje de Fenix; a couple of days after its publication the publisher was given an urgent message by local authorities to stop its distribution. To prevent this from happening again Tjiong and Tan decided to send the subsequent installments to the local council for inspection before they were printed. The irony of this case is that Tjiong was free to insert this story of censorship in the introduction of another sequel. Sometimes power moves in mysterious ways indeed.

Implementing the decree of 1906 meant asking for trouble; journalists and authors challenged authorities in a variety of ways that Batavia and the Hague could not have foreseen and did not know how to counteract effectively. Events around activities of the Inlandsch Comité tot herdenking van Nederlands honderdjarige vrijheid (Native Committee for the Commemoration of One Hundred Years of Liberty of the Netherlands), or the Comité Boemi Poetra (Native Committee), founded in 1913, were a provisional climax in this game of cat and mouse. The committee announced its determination to devote itself to the establishment of a parliament in the Indies, and for the occasion one of its members, Soewardi Soerjaningrat, published an article in Dutch entitled "Als ik eens Nederlander was" (If I were a Dutchman) that could well be read as a mockery of the Dutch-sponsored activities in the colony in celebration of the Netherlands' independence. ${ }^{3}$ The article itself was trenchant enough to create an outburst of anger and indignation in Batavia; when the committee then had the audacity to publish a Malay translation as well, Dutch authorities decided that the time had come to intervene-although not without extensive deliberations about the ideological implications of such a move. The press and its complement-literature-were a constant source of concern. Obviously, the authorities were unable to keep all discursive forces under control; they could try to steer them, and that is what they did. The Dutch distrusted the printed word, which could spread like a moorland fire, invisible but subversive; they feared a domino effect that could bring about the end of the colonial adventure. Yet the methods that the colonizers resorted to in order to neutralize native and Chinese challenges

\footnotetext{
${ }^{2}$ Ph. Kleintjes, Staatsinstellingen van Nederlandsch-Indië (Amsterdam: J. H. de Bussy, 1932), p. 163.

${ }^{3}$ See, for example, Kenji Tsuchiya, Democracy and Leadership-The Rise of the Taman Siswa Movement in Indonesia (Honolulu: University of Hawaii Press, 1987).
} 
to European wisdom and insight at times revealed a paranoia disproportionate to the capacities of the new literates to mobilize the population.

Official bureaucratic correspondence goes slowly, secret and confidential letters go faster, and telegrams go still faster: in the twentieth century a kind of triple-entry bookkeeping evolved among people who usually knew each other very well not only professionally but also personally. It was hard to follow for outsiders and difficult to interpret for subsequent readers. In reply to the minister's official letter quoted, the Governor-General in Batavia had suggested the possibility of developing methods to "take more effective action against efforts to incite a certain spirit in the public that could endanger the interior safety in the colony." Similar suggestions had already been formulated in a secret letter dated October 11,1913, but Batavia's official reply was not sent until January 13,1915-a lapse of more than one year. After seeking the advice of local experts, the Governor-General then wrote to the minister. He was now able to offer two alternative solutions to the problem of controlling the people of the press who appeared to be unable to appreciate freedom of expression in the proper way. One could consider introducing a system of deposit for those who wanted to set up a printing business, a suggestion of the director of the Department of Justice; the other possibility was to the introduce a system of handing out licenses-a suggestion of the Council of the Indies. This official letter was officially answered by the minister on September 17, 1915, half a year later. If the authorities in Batavia had not known that their superior in The Hague was of a different political stamp from his predecessor, they would have been even more puzzled than they already were by the situation in the Indies itself:

When in 1906 freedom of the Press had been gained in the Indies after a struggle of almost fifty years, there was no native press of any political importance. Since then, it has come into being, and it has developed as a result of currents in native society that have broadened and deepened their bases, showing a tendency to gain ground. Far from obstructing these currents, the Government has tried to remove the impediments in their way ... because in the Government's endeavours to develop and emancipate native society free expression of a free opinion is the most prominent among the supportive tools. ... Curbing the press, it has been assumed, serves to stop the worst disasters from happening. I am, however, fully convinced that the gross extravagance of a free press is less dangerous for a community than the dangers which a deeply embittered group of people could create for a society if their mouths are stopped and they are forbidden to speak out. Every opinion expressed in the press that is worth a fight will give rise to objections, objections that in their turn could influence the supporters of that very opinion. 4

These comments were not only enigmatic for readers in Batavia at the time they were written, for a modern reader of the Bronnenpublicaties, too, they are difficult to interpret. Were they meant to be a noble manifestation of ethical thinking or a marvelous illustration of insincerity? One should note that a new article had already been added to the Penal Code of the Indies as early as March 15, 1914, instigated by the Governor-General, and that the article had been given warm support by His Excellency the Minister of Colonial Affairs in The Hague himself:

${ }^{4}$ Van der Wall, De opkomst, pp. 396-97. 
He who incites or encourages feelings of hostility, hate or contempt for the Government of the Netherlands or of the Netherlands Indies by way of words or signs or a performance or by any other way will be punished.... He who incites or encourages feelings of hostility, hate or contempt between the various groups of Dutch citizens or of inhabitants of the Netherlands Indies will be punished. ... Any effort to commit this crime is punishable by law. ${ }^{5}$

In other words, at the time the Minister of Colonial Affairs formulated his official answer and called for restraint in governmental efforts to keep the press under control, problems had already been solved. After 1914, the haatzaai artikelen (hate-sowing articles) gave authorities the power they needed to take action whenever they thought it necessary to do so. That same Minister of Colonial Affairs did not make a serious effort to keep these articles from the new Penal Code that was imposed in 1918. Looking back in 1932, Kleintjes suggested a direct line between 1906 and the new regulations that were introduced in Dutch Indies society in 1931 and gave the Governor-General the right to ban a periodical for up to a year without being required to ask prior advice from the judiciary; those who were directly involved were not given the right to appeal. Interestingly enough, Kleintjes is silent on the introduction of the haatzaai artikelen in 1914-a curious omission indeed, the more so when one realizes that this book was written by a professor of law and was meant to serve as a compass for those who had to work in the Dutch Indies bureaucracy. Events in 1906, 1914, and 1931 could well serve as the framework for a narrative about the changes that the introduction of print brought about in the Indies. In this narrative about literary life, the texts written by Indies inhabitants of Chinese descent were to play an uneasy role, and several forms of censorship were resorted to in order to disqualify the corpus of ChineseMalay literature as a whole.

Early twentieth-century Indies society was full of tensions and possible conflicts; colonial society was supported and suspended by a complicated network of discursive forces that were constantly on the verge of running out of control. Batavia and The Hague were confronted by a growing number of problems and irritations. The primary criterion by which the Dutch leaders maintained order and tranquility in the colony was a policy of racial classification and segregation. Here were the white Europeans, over there were their brown native subjects-and somewhere in between were the groups that were hard to classify: Eurasians, Arabs, and Chinese. This distinction was reflected in and further imposed through the judiciary system; its maintenance was to become an obsession for Dutch authorities, and if the elaborate discussions about the legal status of subjects of the Indies had not been so painful for those who were directly involved at the time, they could have been a source of great amusement for those who are now looking back. In the twentieth century, the Dutch Indies was made a "plural society," as Furnivall called it in 1939, "comprising two or more elements or social orders which live side by side, yet without mingling, in one political unit." 6 "A divided society" is the term that Van Doorn used some forty years later: "Colonial societies are by definition internally divided. They emerge and exist, after all, in virtue of the encounter between the world of the colonizer and the colonized. A dualism is, therefore, always apparent; one which ranges from conflict to cooperation." 7 How exactly

\footnotetext{
${ }^{5}$ For example, see W. A. Engelbrecht, De Nederlandsch-Indische wetboeken (Soerabaja: Führi, 1917), p. 1,086.

6S. Furnivall, Netherlands India. A Study of Plural Economy (Cambridge: Cambridge University Press, 1939), p. 446.

7. van Doorn, A Divided Society: Segmentation and Mediation in Late-Colonial Indonesia (Rotterdam: CASP, 1983), p. 3.
} 
this division took shape in the Indies has already been described by Furnivall, Van Doorn, and many others. Of concern here is the result of this policy of the Dutch, which is very well summarized in the famous report of the Visman Commission, Verslag van de commissie ter bestudering van staatsrechterlijke hervormingen of 1941:

Social intercourse between persons of different race but similar education is, in general, slight, according to the unanimous conclusion of everyone questioned. There is a difference of opinion over the question of whether the developments of the last twenty years should be considered as having brought an improvement or a worsening of conditions. For the rest it is acknowledged that the corporate life of the Indonesian and Chinese population is segregated by race, preventing further social intercourse. ${ }^{8}$

Following these and other witnesses, Van Doorn concludes that late-colonial Indonesia had become a "collection of self-aware population groups, guided by group nationalism." 9 Inhabitants of Chinese descent, too, were increasingly turning inward, keeping to themselves, building group identity, and developing a certain indifference to events that did not directly concern their group interests. Intolerance or ignorance, misunderstanding or indifference, fear or hate-all these words can be used to describe and analyze how the Dutch authorities expressed their opinions about natives and Chinese in the continuous correspondence between Batavia and The Hague. It would, however, be inappropriate to read these reports, letters, and telegrams as only an exchange of views, information, questions, and orders within a small Dutch elite. It could be equally relevant to read texts like the Bronnenpublicaties-only a minimal selection from the archival stacks-as indirect discussions with voices and letters that were emerging "in words, signs and performances" outside the offices in the Indies. Many things were happening "out there" that caused distrust and uneasiness-and called for objection, reaction, and repression. Obviously, newspapers and their editors were to be important discussion partners for the Dutch elite. Their growth in number and variety alarmed authorities. The papers were hard to control, hard to follow, hard to understand; their editors were often invisible and elusive. Bestsellers for a day or two, they were constantly replaced by others, thus creating a new concept of time measured by clocks and calenders rather than by God and rituals. The press contributed to the creation of new imagined communities, opening up and channeling forces that had never been explored before. ${ }^{10}$ The Dutch did not really know how to deal with these changes.

The above quotations from the ongoing correspondence may exemplify Dutch policy in controlling the press: a fluctuating combination of prevention and repression, motivated by a strange amalgam of sentiments-self-righteousness, most of all, but also guilt, insecurity, and the conviction of being among the Lord's selected few. No matter how enlightened administrators in Batavia and politicians in The Hague claimed to be, they believed that administrative repression should remain possible for the sake of order and tranquility, so that economic life and the elevation of the natives could progress undisturbed, and for the sake of quality, so that the natives would develop proper concepts of beauty and morality. These were the two lines of argument in defense of censorship.

Political and moral motivations, both closely related to economic considerations, were equally questionable for the authors and journalists involved. Which was preferable, direct

\footnotetext{
${ }^{8}$ As quoted in Van Doorn, Divided Society, p. 13.

Van Doorn, Divided Society, pp. 15-16.

${ }^{10}$ Benedict Anderson, Imagined Communities: Reflections on the Origin and Spread of Nationalism (London: Verso, 1983).
} 
censorship or criminal persecution after the hate had already been sown? The answers that the authorities formulated to this question were varied and made a univocal policy impossible. What exactly was to be the role of the judiciary? What about simple intimidation? Should these noisy upstarts be silenced right away? It should be pointed out that Batavia may not always have been aware that such doubts could be turned to its advantage as long as they were covered elegantly. After all, a certain degree of capriciousness and arbitrariness is often a more effective tool in keeping people under control than strict maintenance of rules and regulations. Authorities could be challenged, their tolerance tested, but by making it hard to predict their reactions, authors and journalists could be held in constant uncertainty about how to reach and please their publics without running the risk of being persecuted and imprisoned. Civil servant Rinkes, the brightest of them all, wrote the most incisive report on these problems:

During the discussions that I have had concerning the press I have come to realize that a certain part of the public seems to demand a somewhat sensational tone, and that selfrespecting periodicals are usually less successful than those that let their tongues run away with them, and in weekly talks or other occasions they discuss the Government, civil servants, an exhibition, a lottery in a spicy manner indeed, that is to say: they run them down.... (In the Chinese newspaper Warna Warta) the author explains how editors lie between the devil and the deep blue sea and that it is only due to their long experience in matters of criminal offense and their mastery over their pens that they succeed in inserting the required force in their style without running into trouble with a criminal court. ${ }^{11}$

Dutch journalists-white, belonging to the superior caste and often backed by sugar and tobacco-were undoubtedly given more space to criticize authorities, and this caused not only indignation and unrest among ethicists ${ }^{12}$ but also cynicism among their native and Chinese colleagues who were offended by this application of double standards. Although advisors in native and Chinese affairs warned their superiors time and again about this embitterment among Chinese and native literates, colonial authorities were not particularly concerned, convinced as they were that Power was sufficiently tolerant and that journalists did not have any real reason to complain. The fire of the ethicians was slowly smothered and reduced to a mere pilot flame. Draconic measures had already been taken to contain unrest, yet on August 17, 1930, the Governor-General still found sufficient reason to complain about administrative complacency in an official letter to his superior in The Hague:

The fact that both the European and the native press time and again indulge themselves in articles that are directed against the Administration-be it directly or indirectly-with the intention of subverting Authority or belittling office holders in person, doing so in a tone that unnecesarily aggravates and polarizes relationships and tensions between the various races, has for long given cause to consider the question whether and how this could be brought under control. ${ }^{13}$

\footnotetext{
11Van der Wall, De opkomst, p. 389.

${ }^{12}$ See, for example, Jaap de Moor, "De affaire-Asymptoot en de haatzaai-artikelen," in Onderscheid en minderheid, ed. Herman Diederiks and Chris Quispel (Hilversum: Verloren, 1987), pp. 285-302.

${ }^{13}$ R. C. Kwantes, ed., De ontwikkeling van de Nationalistische beweging in Nederlandsch-Indië (Bronnenpublikatie) (derde stuk) (Groningen: Wolters-Noordhoff, 1981), p. 474.
} 
And in his 1930 classic on the ethical policy, which reads like a retrospect rather than a defense, De Kat Angelino could claim without the slightest effort at irony that the tolerance of the administration was still so great that

It is a cause of amazement in native circles-in spite of voices that demand an even greater freedom, and one tends to draw the incorrect conclusion that this tolerance is inspired by fear, guilt or weakness. So that is one of the most dubious consequences of freedom of speech and press in a context which does not yet fully realize the moral implications of a voluntary respect of democratic censorship. ${ }^{14}$

Not only administrative capriciousness, criminal persecution, and pure repression served the Dutch in their efforts to retain power in the Indies. Censorship also took other forms. Racial segregation and the reinforcement of ethnic differences and rivalries resulted in a certain degree of ignorance on all sides, and it was in this atmosphere of mutual distrust that the Dutch succeeded in creating a mystique of zakelijkheid (efficiency) and, closely related to it, of white superiority. This was another form of technocracy and rationality, very much focused on problem solving and, therefore, impressive for those who were not given the opportunity to take a look behind the scenes and the masks. One could also call efficiency pretentiousness (gewichtigheid) as Rinkes did and disapprove as he did of the excessive reaction to any sort of criticism. ("In everything, even in the most simple things, one prefers to act secretly and pretentiously, defending the inaccessability of those beloved documents stored in impressive and opaque portfolios")..$^{15}$ In both terms, efficiency and pretentiousness, the fears and uncertainties that so often go with ignorance and misunderstandings are silenced.

Even more effective in the long run than any of the methods mentioned so far was the introduction of an educational system: it was rightly perceived as the method par excellence to provide the population with the appropriate insights and skills. Throughout the years, the system extended and refined its reach by ramifications and furcations, and the variety of school types and subtypes was so dazzling that one could wonder if the director of Education in Batavia himself was able to keep up with the changes and modifications, let alone the educationalists in the schools themselves. The concepts that made the school system work were simple: race, status, and wealth, in that order of importance. In the eyes of the ethicists as well as those with economic interests in the Indies, education should keep the whites aware of their special mission to elevate and civilize the natives and stop these self-educated Chinese from developing their own methods of exploring the wonders of this world. The educational system was another tool to keep the races as separate as possible, to gain control over discourse and discursive practices, and to safeguard a useful ritualization of speech and the relevant distribution of knowledge. Since the first discussions in the Indies around 1850 about the desirability of education, the question of which language could effectively be made the vehicle for administration, knowledge, and politics through the educational system had been the central interest. At the end of the nineteenth century the authorities had reached a consensus on the subject: Dutch was to be restricted to the happy few, whereas "Malay" was to be the common language of the Dutch Indies, preferred to the local languages.

Indies Malay was in reality the outcome of centuries of controversy about when and how Dutch, Portuguese, High or Low Malay, Javanese, and many other Indies vernacu-

${ }^{14}$ A.D.A. de Kat Angelino, Staatkundig beleid en bestuurszorg in Nederlandsch-Indië (The Hague: Nijhoff, 1930), p. 1, 154.

15Van der Wall, De opkomst, p. 395. 
lar tongues were to be used in trading stations, churches, diplomatic dealings and, later on, in both territorial government and the production of agricultural exports. ${ }^{16}$

What kind of Malay was this "Indies Malay?" What kind of Malay did the Dutch really have in mind? For centuries, the vehicle of communication that in its various local forms held the Malays together in a cultural identity of sorts had spread from the Malay heartland over the archipelago. Particularly in the urban areas around the Java Sea where people of so many ethnicities met, it had become the best discursive vehicle for passing on fragments of information. The interaction of forms of Malay with other local languages resulted in the emergence of a variety of pidgins; some of these pidgins, in turn, gradually developed into creoles in which elements from Malay were the dominant feature, providing its users with a distinct identity. During the nineteenth century, the use of these forms of Malay intensified: interinsular traffic increased, urban centers grew in size and importance, and Dutch Indies authorities further stimulated the use of Malay in their efforts to facilitate communication between representatives of the various ethnicities.

Discussions on what was meant by "the Malay language" were heated and lively, the brawls between scholars like Van der Tuuk, Vondewall, and Klinkert being some of the most amusing in our field. There were sufficient reasons for these emotional exchanges. There were the purely scholarly questions of what Malay essentially was, where it was spoken, and which was its correct form. There was the question of scholarly authority-who was "in the true," to use a Foucouldian term, and who was not. And, not the least important was the question of money: the expanding educational system badly needed textbooks and primers, and no doubt writing these schoolbooks was to be a profitable undertaking. In short, much was at stake. These discussions on Malay, however, were not based on a wellbalanced appreciation of the problems involved-and surprisingly enough, up to 1942 they never would be. What exactly were the various forms of Malay? And how could one distinguish them? How should a standard be determined and formulated? How was one to describe and order the continuum between the forms of Malay of the Malay Peninsula and Sumatra? How should one describe and analyze the differences between written and oral forms, between older and contemporaneous forms and, most importantly, between pidgin and creole forms? No observer, no scholar had ever been able to appreciate fully such questions, and the tone of puzzlement that permeates the observations of the philologist Hooykaas on the subject shortly before the fall of Dutch power is quite justified: a solid study of these related forms of discourse that together were called Malay had never been undertaken during the entire colonial period. ${ }^{17}$

Insofar as Malay was seriously studied at all, it was always done with a clearly prescriptive aim to organize this language so that it could uniformly be used in a wide variety of situations: teaching the natives, conducting correspondence with native princes and Chinese captains, performing ritual meetings, and formulating tax forms, advertisements, legal verdicts, and railroad timetables. Those who were given the opportunity to study the language, thanks to an assignment by administration, mission, or company, tended to distinguish between Malay as a "language of communication" (verkeerstaal) and Malay as a "language of culture" (cultuurtaal). The forms of Malay that administrators usually confronted were seen as examples of the "language of communication"; therefore, they were incomplete and bad, apparently for the simple reason that they were not forms of Malay spoken by the Malays

16]. Hoffman, "A Foreign Investment, Indies Malay to 1901," Indonesia 27 (1979): 65-92.

${ }^{17} \mathrm{~A}$ retrospective summary can be found in C. Hooykaas, "Modern Maleisch," in Koloniale studiën 1939, pp. 40538. 
themselves. The term "Laag Maleis" (Low Malay) alone speaks volumes. People of Chinese descent in the urban centers, for instance, used versions of Malay that were widely regarded as gibberish-mere versions of this Low Malay, not to be taken seriously, not to be studied, and not worth any attention. Originating among Chinese immigrants as forms of pidgin, these versions of Malay had developed through generations of speakers-and writers-into a number of creoles, absorbing and rejecting in the process elements of other discourses around them. Thanks to the spread of newspapers and books that used these versions, they were fast converging into a distinct cultuurtaal, the very type of language educationalists and scholars were so desperately trying to create in the 1920s, unaware that they did not have to leave their towns-Batavia, Surabaya, Semarang-to find one in full operation.

The standard Malay-to-be was sought primarily in the Malay homeland, Sumatra's east coast, where Malay was used as a cultuurtaal. It was possible to be even more specific: the search for a standard Malay focused on the Riau archipelago which, as some Malays kept telling their Dutch overlords, was the cradle of Malay culture. Riau was accorded this status largely because of the manuscripts that had been produced there, considered by many to be the climax of the Malay heritage. It is easier to sit in a chair than to stand in the mud of the Sumatran east coast, and should not that written tradition be regarded as the apex of Malay culture, in the same way written texts are seen as the nucleus of European culture? On the instigation of Van Ophuysen, its architect if not its inventor, a form of Malay called "Riouw Maleisch" was proclaimed to be the standard. It was a mere combination of various forms of Malay Van Ophuysen had found and collated during his journey in the Malay world, and, therefore, it was in practice nobody's Malay. This Riouw Maleisch was the form that was prescribed for primary and secondary schools through the text books and reading materials distributed by the authorities. Not until the late twenties, it seems, did administrators realize that these school materials offered a form of Malay that was quite different from the forms of Malay that were used in native circles. In 1927, the Director of Education wrote to his superior:

There is a yawning abyss between the Riouw Maleisch that is officially prescribed at schools and the civilized Malay [beschaafd Maleisch] that here in Java is rather common in daily contacts, in meetings and in the press, be it with local varieties. If education is to serve its purpose and wants to be accepted on a wider scale, Riouw Maleisch should be replaced by a form of Malay that is closer to the more common language of conversation and writing. [Experts agree that] it is possible to design a school Malay that is rooted in living language but ... in that case several difficulties have to be solved first, e.g. the fact that outside the Riouw Maleisch of textbooks little unity can be discerned in the way of writing and speaking of the so-called civilized Malay which is developing in the free society and in which Chinese journalists play an important role. ${ }^{18}$

Two years later, the newly appointed Director of Education rejected his predecessor's suggestion of replacing textbooks in Riouw Maleisch with textbooks in another version of Malay. Such a replacement was "practically impossible," he wrote, and did not the Bureau voor de Volkslectuur do very good work indeed in cultivating the new sort of Malay? No, for the time being texts in Riouw Maleisch would suffice, if only because they provided the pupils with an adequate basis for the understanding of any other kind of Malay. ${ }^{19}$ One must seriously question, however, whether pupils of Chinese descent were able to understand this Riouw Maleisch and, conversely, whether they were provided with an adequate basis

\footnotetext{
${ }^{18}$ S. L. van der Wall, Het onderwijsbeleid in Nederlands-Indië (Groningen: Wolters, 1963), pp. 419-29.

${ }^{19}$ Ibid., p. $485 \mathrm{ff}$.
} 
for understanding other types of Malay. Not without reason did natives call this form of Malay "Bahasa Belanda," as Hooykaas observed with slight amusement, and, with due respect to Van Ophuysen's endeavors, one might add that Riouw Maleisch was not the form of language that was spoken and written in Riau either. "Malay language" is a deceptive term, as the word language is in general: it suggests a unity, a basis that simply does not exist in the real world. In Southeast Asia, like anywhere else where there are human communities, all sorts of more or less closely related forms of verbal communication were used by various groups, and each of those forms had a distinct place, discontinous and juxtaposed with other forms of discourse in a hazy network of constantly changing similarities and differences. In this network of discursive practices it was up to political and economic centers to decide which of these forms were to be varieties of the "Malay language" and which of these varieties of Malay was to have special authority. Riouw Maleisch was a political myth; it was an artifically created form of Malay that belonged to no one. Through the aggressive campaigns of the Dutch Indies government alone it was made to work; as beschaafd Maleis (civilized Malay) it was to form the basis for a new culture that would lead the native population of the colony into the modern world.

In this preference for a particular form of Malay, procedures of exclusion, selection, and prohibition were effected; not everybody had the right to speak up about everything. This was a more delicate manner of censorship, of which even those in power were not always fully aware. A matter of hegemony, censorship worked in the Indies as it works everywhere else. The introduction of this new Malay through textbooks and readers had far-reaching consequences: a generation of well-educated literates emerged that in due course gained a very effective influence over the language policy that authorities developed in their efforts to bring the process of disintegration and segregation within colonial society to a halt. This process could be described in the reverse as well: other forms of Malay were pushed into the margin because they lacked the authority to maintain themselves in the center. Literary life, too, took on a new configuration. Particularly as a result of the spread of print, two groups were able to seize power over the written word and, accordingly, over the distribution of knowledge. One group consisted of the Chinese Malays who were developing their own identity on the basis of a version of Low Malay, a colonial term they tended to regard as a term of honor. The second group comprised the native intellectuals who had become familiar with the standard of Riouw Maleisch through their education and who operated in close cooperation with government institutions. In 1927, Kwee Tek Hoay still had the courage to write, "We believe that Low Malay will eventually overcome and completely destroy Riau Malay or Ophuysen Malay which is now still protected by the Administration," but this expectation did not come true. ${ }^{20}$ In the thirties, the leading proponent of the new Malay, Takdir Alisjahbana, educated by the Dutch and employed by Balai Poestaka, a governmentsupported institution, ${ }^{21}$ could write in that eerie tone of self-confident distrust so characteristic of the Indies' native intelligentsia:

Moreover, the integration of Indonesian with Chinese Malay will take place faster if only certain groups within the community of people of Chinese descent regarded this land as their fatherland and dissociated themselves from Chinese nationalists. . . . If only their children sat with Indonesian children in the benches of national Indonesian schools that

\footnotetext{
${ }^{20}$ Quoted in Claudine Salmon, Literature in Malay by the Chinese of Indonesia-A Provisional Annotated Bibliography (Paris: Editions de la Maison des Sciences de l'homme, 1981), p. 116.

${ }^{21}$ For a (positive) description of Balai Poestaka and its activities see A. Teeuw, "The Impact of Balai Pustaka on Modern Indonesian Literature," in Bulletin of the School of Oriental and African Studies 35 (1972): 111-27.
} 
emphasized the importance of Indonesian, then Indonesian would automatically become their language, too. 22

Neither Kwee's expectation nor Takdir's wish was to come true in the near future. Convergence of the varieties of Malay remained a mere dream as long as the Dutch kept the speakers of Malay divided and ruled their colony in growing anxiety. How should they keep discursive formations under control?

Conflicts and tensions among discursive formations can be traced through more than textbooks and political meetings; in literary life, too, the struggle for authority can be found and described to historicize the interactions among societal forces. In the wake of the appearance of newspapers and other periodicals, Malay literary life took on a new configuration after 1870 . Malay speakers of Chinese descent played the leading role in this, as authors, publishers, and readers, and through them, Creole-like forms of Malay started to interact with the Malay forms in manuscripts and lithographs, which merely emulated literary elements of the Malay heritage, the syair and the hikayat. New forms emerged: short verses, short stories, and most importantly, novels, which, both in originals and translations, were to take the most prominent position in these literary developments. In this, Malay literary life followed a familiar pattern. In a convenient gloss on Anderson's Imagined Communities, ${ }^{23}$ Brennan describes the interrelated emergence of nation, novel, and newspapers as follows:

It was the novel that historically accompanied the rise of nations by objectifying the "one, yet many" of national life, and by mimicking the structure of the nation, a clearly bordered jumble of languages and styles. Socially, the novel joined the newspaper as the major vehicle of the national print media, helping to standardize language, encourage literacy, and remove mutual incomprehensibility. But it did much more than that. Its manner of presentation allowed people to imagine the special community that was the nation. 24

Less than one decade after the royal decree had guaranteed freedom to the press, Dutch administrators began to express their worries about quality and about tendencies they discerned in Malay publications, not only in articles and serials in periodicals but also in novels and other texts. These publications were considered politically dangerous, morally suspicious, and, therefore, a threat to peace and tranquility. Then the Bureau van de Volkslectuur (Bureau for Popular Reading)-later renamed Balai Poestaka-was founded. In the words of its main instigator, Rinkes:

The government has taken the initiative to elevate the population in a systematic manner, and it is to become clear from the application and appreciation of the principles that will be developed by the native population itself whether it wants to continue along this road or not. It is in the interests of its existence as a nation that its development is led along the same path that almost all other nations follow towards progress. A first effort has been made, but it is obviously the task of the more developed persons among the

\footnotetext{
${ }^{22}$ S. Takdir Alisjahbana, "Kedudukan bahasa Melaju-Tionghoa," in Dari perjuangan dan pertumbuhan Bahasa Indonesia (Jakarta: Pustaka Rakyat, 1957), p. 61.

${ }^{23}$ Anderson, Imagined Communities.

${ }^{24}$ T. Brennan, "The National Longing for Form," in Nation and Narration, ed. Homi K. Bhaba, (London: Routledge, 1990), p. 49.
} 
native population itself to show their fellow countrymen the way and to offer them the proper tools to find the proper paths towards progress. ${ }^{25}$

The bureau was meant to stand on its own commercial feet, and apparently it did. Ideologically, however, it was clearly an extension of colonial authorities. Balai Poestaka could nicely serve Batavia's efforts to keep the natives away from all those subversive forces that were emerging throughout society, and, therefore, the bureau was provided with the facilities that it needed to build respect and prestige and fulfill its objectives in the proper manner. Counterpropaganda Rinkes had called it in an early proposal; that same term came up some ten years later in a confidential report that circulated in the Department of Interior Affairs about the role this institution could possibly play in the Indies:

In the case of direct propaganda nothing much can be accomplished for the time being [but in other ways things seem possible]. The Government should see to it that the people who want to educate themselves without being driven by feelings of dissatisfaction are given food for their minds so that they will not end up in the ranks of our rivals. And secondly-more important but also more difficult-one could try to spread the view that anyone who wants to improve his country can do so most effectively by supporting this Government. Up to a point this is counter-propaganda to extremism and communism although in a indirect manner only ... and by taking "natural" nationalistic emotions into account. ${ }^{26}$

The books that were published by Balai Poestaka constituted the nucleus of the library of every government-sponsored school; they were the logical extension of the textbooks and primers and must have had considerable influence on the thinking of young readers. An aggressive sales policy, sometimes with stickers, lotteries, and other promotional gimmicks, secured the publishers a distribution of their books outside the schools that was difficult for competitors to surpass. Supported by the educational system as a whole, Balai Poestaka was able to play a dominant role in leading the native population toward modernity but also to contribute very actively to the shaping of the canon of modern Malay literature-a native manifestation of the hegemony of the Dutch who, once having achieved direction over the decisive economic nucleus, were able to expand this into a moment of social, political, and cultural leadership and authority throughout Dutch Indies society. ${ }^{27}$ Within the discourse imposed by Dutch hegemony, certain procedures could be neutralized, certain channels to knowledge blocked. The use of forms of Malay that differed too much from the standard Balai Poestaka tried to develop was discouraged, for instance. Certain subjects were to be avoided: sex, politics, and religion. These evasions constituted considerable delimitations, if not prohibitions-or should they be called repression? Undesirable discussions could be silenced, and authors who were thought to be subversive, deviating, and mad-dangerous, that is - could be intimidated and disgraced. Such were the techniques authorities resorted to in order to strengthen their hegemony. Reformulating a tradition, shaping a canon-censorship can be implemented by active repression, through prevention, through a welldesigned system of education, through an aggressive sales policy, and through pretentiousness and efficiency. All of these are forms of censorship, but they are not enough to ensure success. To push possible rivals into the margin and beyond, those strategies need a complement-possible competitors must be discredited. No doubt, the situation was favorable for the Volkslectuur: in the shadow of Batavia it worked "in the true," and, equally impor-

\footnotetext{
${ }^{25}$ D. Rinkes, Nota over de Volkslectuur (Batavia: Volkslectuur, 1912), pp. 3-4.

26Van der Wall, Het onderwijsbeleid, p. 263.

${ }^{27}$ S. Hall et al., Culture, Media, Language (London: Hutchinson, 1980), p. 35.
} 
tant, the main competitor to its publications was the fast-growing corpus of texts produced by Chinese-Malay authors and publishers, which emerged in a circle of readers who were increasingly isolated from both the natives and their colonial masters, politically, economically, and ideologically. This was a strong circle that was certain not to break open again during the colonial period. In their drive to create a canon of "good literature," the European leaders of the newly created Malay literary life were blind, or at least pretended to be blind, to the impressive activities that were taking place outside the buildings of Balai Poestaka. Their attitude is exemplified by the article that Drewes, long the director of the Balai Poestaka, published about contemporary developments in literary life in 1932:

It would be hard indeed to underestimate the important role that the Administration plays in keeping control over the development of good taste in this time of transition. There is the obvious danger that those who are looking for something they are wanting so badly end up in reading materials of dubious quality. . . . Less conscientious publishers manage to cash in on this tendency to realism (for want of a better term), and with its cheap products the Volkslectuur has been able to exercise a beneficial influence here: it succeeded in pushing back the usually very expensive Schund literatur [trashy literature] that those Chinese publishers are trying to sell. ${ }^{28}$

In the paragraph preceding this quotation, Drewer shows that authority had already started to discredit Balai Poestaka's rivals by referring to the dubious role the ChineseMalay press had played in the formation of the new style of prose, "which only rarely becomes well-polished prose." Chinese-Malay literature was a mere commodity, he suggests; it made use of a language of communication and not of a language of culture, to use the terms of the day, and it tried to sell rather than to elevate-a very effective method to freeze the yawning gap mentioned by the Director of Education, He proposes that a distinction exists between two kinds of literature, two kinds of art: "good art" and "bad art," "real art" and "popular art." Even though in the Dutch Indies this distinction may not have run parallel to the distinction between an educated class and "the rest," the distinction Drewes makes is a relevant one.

Authors like Kwee Tek Hoay and Monsieur d'Amour, to mention just two, may have been unwilling to give in to linguistic and thematic demands, and they lacked the political (and educational) patronage that could have guaranteeed them a place "in the true." In the shadow of such explicit disqualifications by authority, they were excluded. Their position was an ambivalent one. On the one hand, they wanted to operate on a commercial basis and, therefore, had to attract as many readers as possible through more sexual innuendos, more violence, more action. On the other hand, they thought they had a task in their own communities: to make some sort of contribution to a distinct Indies Chinese identity, even in a basically hostile society. Perhaps Chinese-Malay literature should be seen as a counter literature, a corpus of texts that was not accepted by a small group of people whose function in the sociocultural establishment gave them the authority to pass judgment. The most intriguing word in Drewes' remarks is, of course, Schund-literatur, a derogatory reference to a corpus of texts that must have been at least fifty times larger than the production of Balai Poestaka: immoral, sensual, and, therefore, malignant and dangerous. Some mildly pornographic texts were indeed published by Chinese enterprises (the publication of Perhoeboengan Rasia in Semarang in 1937 comes to mind), but such books were rare, and it is, there-

\footnotetext{
${ }^{28}$ G.W.J. Drewes, "Oud en nieuw in de hedendaagse Indonesische litteratuur," in De Gids 96 (1932): 330. ("Schund literatur" is a German term with a distinctly negative connotation; it could be translated as "trashy literature," "rubbish".)
} 
fore, an inappropriate term for the corpus as a whole. To use so derogatory a term was an embarrassing way to discredit elements that could not be brought under immediate control, and was made even more embarrassing because any illustration in support of this insinuation was lacking.

Schund-literatur-the term occurred again in Hooykaas's Over Maleise literatuur, the first handbook on Malay literature for native students, published in 1937:

Not only did they just write for the sake of writing, in a careless language, but they also treated inappropriate subjects. In short, all sorts of Schund appeared on the market, and in huge quantities. The Government thought it appropriate to interfere: by giving suitable reading material to its tens of thousands of matriculants it wanted to repress whatever was considered politically and morally unsuitable. ${ }^{29}$

This is another quotation that could be used in many ways. In a single sentence, Hooykaas discredited the language of Chinese-Malay literature and the intentions of its authors. All sorts and huge are slightly exaggerated terms. It is well-nigh possible that the Chinese-Malay literates who are criticized here no longer felt that such a remark was a slap in the face; interaction between them and "the others" had become very rare indeed.

One year after Drewes published his ill-founded disqualification of Chinese-Malay literature as a whole, a new phase in Dutch cultural policy was initiated: a self-proclaimed avant-garde came onto the scene in Batavia in the form of a "cultural journal," Poedjangga Baroe (The new poet). Most of its leaders and contributors had received a Dutch-controlled education; it was clearly visible not only in the ideas and concepts they propagated but also in the form of Malay they used, very similar to the Malay used by Balai Poestaka. This similarity is not surprising because its editors were closely associated with this showpiece of colonial wisdom. Following the lead of Dutch authority, Takdir Alisjahbana, too, presented the forms of Malay the Chinese were using in their conversations and their books in a derogatory manner-as though his own "Bahasa Indonesia" were already a full-fledged cultuurtaal and Chinese-Malay were not and never could be.

In the same vein, this group of self-confident young intellectuals was keen to denounce Chinese-Malay literature, if only to establish their own importance in literary life and to create the atmosphere that an avant-garde needs to gain authority and prestige. In and after the Japanese occupation of the archipelago this self-confidence was amply rewarded. Japanese authorities banned the use of Dutch, and in their efforts to stimulate the use of Malay they continued the policy of the Dutch; Takdir and some of his friends were to become important advisors in the continuous construction of a Bahasa Indonesia, and the form of Malay that had been developed by Balai Poestaka (and Poedjangga Baroe) was to serve as a standard. Of course, this resulted in a further marginalization of Chinese-Malay language and literature. The derogatory attitude that the Poedjangga Baroe people, like the Dutch authorities, had shown for their rivals was continued by the generation of artists that arose in the wake of the Revolution. In their often violent reactions against their forerunners in Balai Poestaka and Poedjangga Baroe, authors like Chairil Anwar and Sitor Situmorang did not look for inspiration in the rich Malay-Chinese tradition but preferred to seek it in Western and regional examples. Interaction between the two mainstreams of Malay literature appeared farther away than ever. And to follow the tradition of derogation and disqualification to the end: in this survey of modern Indonesian literature published by the prominent

${ }^{29}$ C. Hooykaas, Over Maleise literatuur (Leiden: Brill, 1937), p. 193. 
Poedjangga Baroe member Armijn Pane in 1949, Chinese-Malay literature was denounced as once again Schund-literatur:

The newspaper, a Western product, brings the dead prose to life again. The transient everyday life: the news needs to be told, first in the long-winded narrative style of the old prose, later short and powerful, sharp and clear, "to the point": the new style, the new prose was born. Carried along by real life it went astray from the straight and narrow to the Schund-literatur. In 1908 the Commisie voor de Volsklectuur was installed, initially meant to meet the needs of pupils and former pupils of the ... schools, later to be a beacon in the modern world with its new needs. ${ }^{30}$

The disqualification remained the same, as did the fear and distrust. The political and practical problems the Chinese-Malay tradition was to confront in the fifties forced its supporters to keep a low profile. The lack of appreciation and interest from the new literary elites, who so eagerly tried to replace their Dutch masters, was a final blow, it seems, for the continuation of this rich tradition, a tradition that still awaits a careful study.

${ }^{30}$ Armijin Pane, Kort overzicht van de moderne Indonesische literatuur (Jakarta, Balai Pustaka, 1949), p. 13. 
